\title{
Sclareol, a plant diterpene, exhibits potent antiproliferative effects via the induction of apoptosis and mitochondrial membrane potential loss in osteosarcoma cancer cells
}

\author{
LIN WANG* , HONG-SHENG HE* , HUA-LONG YU, YUN ZENG, HENG HAN, NING HE, \\ ZHI-GANG LIU, ZHI-YONG WANG, SHOU-JIA XU and MIN XIONG
}

Department of Orthopedics Institute, Affiliated Dongfeng Hospital, Hubei University of Medicine,

Shiyan, Hubei 442008, P.R. China

Received March 28, 2014; Accepted August 11, 2014

DOI: $10.3892 / \mathrm{mmr} .2015 .3325$

\begin{abstract}
The objective of the current study was to evaluate the antiproliferative activity of sclareol against MG63 osteosarcoma cells. A 3-(4,5-dimethylthiazol-2-yl)-2,5-diphenyltetrazolium bromide assay was used to evaluate the cell viability of cells following treatment with sclareol. The extent of cell death induced by sclareol was evaluated using a lactate dehydrogenase (LDH) assay. The effect of sclareol on cell cycle progression and mitochondrial membrane potential $(\Lambda \Psi \mathrm{m})$ was evaluated with flow cytometry using the DNA-binding fluorescent dyes propidium iodide and rhodamine-123, respectively. Fluorescence microscopy was used to detect the morphological changes in the MG63 osteosarcoma cancer cells and the appearance of apoptotic bodies following sclareol treatment. The results revealed that sclareol induced dose- and time-dependent growth inhibition of MG63 cancer cells with an $\mathrm{IC}_{50}$ value of $65.2 \mu \mathrm{M}$ following a 12-h incubation. Furthermore, sclareol induced a significant increase in the release of LDH from MG63 cell cultures, which was much more pronounced at higher doses. Fluorescence microscopy revealed that sclareol induced characteristic morphological features of apoptosis and the appearance of apoptotic bodies. Flow cytometry revealed that sclareol induced $\mathrm{G}_{1}$-phase cell cycle arrest, which showed significant dose-dependence. Additionally, sclareol induced a progressive and dose-dependent reduction in the $\Lambda \Psi \mathrm{m}$. In summary, sclareol inhibits the growth of osteosarcoma cancer cells via the induction of
\end{abstract}

Correspondence to: Professor Min Xiong, Department of Orthopedics Institute, Affiliated Dongfeng Hospital, Hubei University of Medicine, 16 Daling Road, Shiyan, Hubei 442008, P.R. China

Email: anatomyvacant201401@gmail.com

${ }^{*}$ Contributed equally

Key words: sclareol, antiproliferative, apoptosis, cell cycle, mitochondrial membrane potential apoptosis, which is accompanied by $\mathrm{G}_{1}$-phase cell cycle arrest and loss of $\Lambda \Psi \mathrm{m}$.

\section{Introduction}

Programmed cell death, or apoptosis, has a key role in the regulation of cell division and a number of developmental processes. The hallmarks of apoptosis include cell shrinkage, nuclear condensation, membrane blebbing, DNA fragmentation and the appearance of apoptotic bodies (1). It has been reported that numerous antitumor agents act via the induction of apoptosis in order to curb tumor promotion and progression. A family of proteases known as caspases are activated in cells undergoing apoptosis, which results in the onset of a number of molecular and structural changes, including the condensation of nuclear heterochromatin, cell shrinkage and the degradation of DNA repair enzymes (polyribose polymerase; PARP), and DNA-dependent protein kinases. The apoptotic bodies that form following apoptosis are then phagocytocysed by neighboring cells or macrophages (2).

Osteosarcoma is the most prevalent type of malignant bone tumor in children and teenagers as well as the eighth most commonly occurring carcinoma in children, which accounts for $2.4 \%$ of all pediatric cancers and $20 \%$ of all primary bone cancers. Osteosarcoma have been reported to be more prevalent in males compared with females, with the highest rates of occurrence during adolescence $(3,4)$.

In the past two decades, chemotherapy and surgery have been the primary therapies used in the treatment of osteosarcoma. However, there are various complications associated with the intense doses of chemotherapeutic agents that patients receive. A number of osteosarcoma patients do not show any response to chemotherapy due to the development of multidrug resistance in the cancer cells. Furthermore, there are numerous serious side-effects associated with chemotherapy, including impaired renal function, gonadal dysfunction and cardiac dysfunction (5-8). Hence, there is an urgent requirement for novel, safer therapeutic approaches for the treatment of osteosarcoma.

In the current study, the anticancer effects of sclareol, a plant-derived diterpene, were investigated against osteosarcoma cancer cells in vitro. The study examined the 
effects of sclareol on MG63 human osteosarcoma cancer cells using a 3-(4,5-dimethyl-thiazol-2-yl)-2,5-diphenyltetrazolium bromide (MTT) assay. Flow cytometry and fluorescence microscopy were used to examine the effect of sclareol on the induction of apoptosis and the loss of mitochondrial membrane potential $(\Lambda \Psi \mathrm{m})$ in osteosarcoma cells. To the best of our knowledge, no previous studies have investigated the effect of this plant-derived diterpene on osteosarcoma.

\section{Materials and methods}

Cell culture and treatment. MG63 human osteosarcoma cancer cells were procured from the Shanghai Institute of Cell Biology (Shanghai, China). The cancer cells were grown in Eagle's minimal essential medium (Gibco-BRL, Carlsbad, CA, USA) supplemented with $5 \%(\mathrm{v} / \mathrm{v})$ fetal bovine serum (FBS; Sigma, St. Louis, MO, USA), 2 mM L-glutamine, 100 U/ml penicillin and $100 \mu \mathrm{g} / \mathrm{ml}$ streptomycin (Gibco-BRL, Carlsbad, CA, USA). The cells were allowed to attach for $2 \mathrm{~h}$ prior to the addition of sclareol. The cells were maintained at $37^{\circ} \mathrm{C}$ in a humidified atmosphere containing $5 \%(\mathrm{v} / \mathrm{v}) \mathrm{CO}_{2}$. Sclareol (Sigma) was dissolved in DMSO at $10 \mathrm{mg} / \mathrm{ml}$ as a stock solution and diluted to the necessary concentration with fresh medium prior to use. The final DMSO concentration in the cultures was $<0.1 \%(\mathrm{v} / \mathrm{v})$, which did not influence cell growth when compared with that of the vehicle-free controls. Cells were grown in the media containing an equivalent amount of DMSO without sclareol to serve as a negative control.

MTT assay for cell viability. An MTT assay (Sigma) was used to assess cell viability. Briefly, cells were seeded in 96-well plates at a density of $1 \times 10^{6}$ cells/well. Following a $12-\mathrm{h}$ incubation, sclareol $(10,30,50,70$ or $100 \mu \mathrm{M})$ was added to the cells, while DMSO served as a negative control. The cells were cultured for 12,24 and $48 \mathrm{~h}$, followed by incubation with MTT $(0.5 \mathrm{mg} / \mathrm{ml})$ for $3 \mathrm{~h}$ at $37^{\circ} \mathrm{C}$. Water-insoluble formazan crystals formed during incubation, which were dissolved by the addition of $100 \mu \mathrm{l} /$ well DMSO. The optical densities (OD) at $570 \mathrm{~nm}$ were measured using an immunosorbent assay plate reader (HR801; Shenzhen Highcreation Technology Co., Ltd. Guangdong, China). Wells that contained culture medium and MTT but no cells acted as blanks. The percentage cell viability was calculated with the following equation: Cell viability $=\left(\mathrm{OD}_{\mathrm{drug}}-\mathrm{OD}_{\text {blank }} / \mathrm{OD}_{\text {control }}-\mathrm{OD}_{\text {blank }}\right) \times 100$.

Lactate dehydrogenase $(\mathrm{LDH})$ release assay. An $\mathrm{LDH}$ assay was performed using a CytoTox $96{ }^{\circledR}$ Non-Radioactive Cytotoxicity Assay kit from Promega (Madison, WI, USA). Cells were seeded at a density of $2 \times 10^{5}$ cells per well into 24 -well plates $12 \mathrm{~h}$ prior to the experiments. Following different treatments, media from each well was collected to quantify the amount of released LDH, whereas isolated wells exposed to lysis buffer (10\% Triton X-100) and media were collected to measure the total amount of cellular LDH. Cellular LDH was measured using a Cytotoxicity Detection kit (Roche Pharmaceutical Co., Basal, Switzerland) and a Colorimetric microplate reader (Thermo Molecular Devices Co.). Lactate dehydrogenase activity was determined by change in absorbance at $490 \mathrm{~nm}$. For the purpose of calculating percent cytotoxicity values, background LDH release from culture cells was considered as low control and triton-X $100(0.01 \%)$ treated cells as high control. Leakage $(\%)=[$ A490 (sample)-A490 (low control)/A490 (high control) - A490 (low control)]x100\%

Detection of apoptosis. Cells grown in 12-well plates on coverslips were exposed to different concentrations $(30,50,70$ and $100 \mu \mathrm{M}$ ) of sclareol for $48 \mathrm{~h}$ and incubated with Hoechst 33258 (Hoechst Staining kit; Beyotime Biotechnology, Haimen, China) according to the manufacturer's instructions. Fluorescence microscopy was used to monitor changes in cell shape; cells were washed once with PBS, and then observed under a RX50-RFL Biological fluorescence microscope (Nikon, Tokyo, Japan). The condensed DNA of apoptotic cells was identified by intense local staining in the nucleus, in contrast to diffused staining of DNA in normal cells. Cell morphology was evaluated from six random visual fields and minimum of 600 cells were counted; each experiment was performed in triplicate.

Measurement of the effect of sclareol on cell cycle phase distribution. MG63 osteosarcoma cells $\left(1 \times 10^{6}\right)$ in a $60-\mathrm{mm}$ dish were exposed to varying concentrations (50, 70 and $100 \mu \mathrm{M}$ ) of sclareol for $48 \mathrm{~h}$. The cells were collected by trypsinization and washed twice with phosphate-buffered saline (PBS; Guangzhou Geneshun Biotech, Ltd, Guangzhou, China). Cells were incubated in $60 \%$ ethanol at $-20^{\circ} \mathrm{C}$ overnight and then treated with $40 \mu \mathrm{g} / \mathrm{ml}$ RNase A (Guangzhou Geneshun Biotech, Ltd) and stained with $20 \mu \mathrm{g} / \mathrm{ml}$ of propidium iodide (PI; Guangzhou Geneshun Biotech, Ltd). The stained cells were analyzed using a FACScan flow cytometer (BD Biosciences, San Jose, CA, USA) at a wavelength of $488 \mathrm{~nm}$.

Measurement of the effect of sclareol on $\Lambda \Psi m$. The $\Lambda \Psi \mathrm{m}$ in MG63 cells was measured with rhodamine 123 (Rh-123; Guangzhou Geneshun Biotech Ltd) dye. MG63 osteosarcoma cells $\left(5 \times 10^{5}\right)$ were treated with different concentrations $(50$, 70 and $100 \mu \mathrm{M}$ ) of sclareol and the $\Lambda \Psi \mathrm{m}$ was measured by flow cytometry. Rh-123 (5 mM) was added $2 \mathrm{~h}$ prior to the termination of experiment. The cells were then washed with PBS and incubated with PI $(20 \mu \mathrm{g} / \mathrm{ml})$ for $30 \mathrm{~min}$. The cells were analyzed using a FACScan flow cytometer.

Statistical analysis. The data are expressed as the mean \pm standard deviation. Differences between two groups were analyzed using Student's t-test and $\mathrm{P}<0.05$ was considered to indicate a statistically significant difference.

\section{Results}

Sclareol has an antiproliferative effect on MG63 osteosarcoma cells. The antiproliferative activity of sclareol was evaluated against cultured MG63 cells using an MTT assay following 12, 24 and $48 \mathrm{~h}$ incubation intervals. The osteosarcoma cancer cells showed susceptibility to treatment with increasing doses of sclareol. Sclareol displayed dose- and time-dependent inhibition of cancer cell growth as presented in Fig. 1. The $\mathrm{IC}_{50}$ value of the drug was found to be $65.2 \mu \mathrm{M}$ at $12 \mathrm{~h}$ of incubation. Following a 48-h incubation, growth inhibition was observed compared with the growth at 12- and 24-h incubation intervals. 
Evaluation of sclareol-induced cell death with an $\mathrm{LDH}$ release assay. To examine whether sclareol induces cell death in human MG63 osteosarcoma cancer cells, groups of cells were exposed to different concentrations $(10,30,50,70$ and $100 \mu \mathrm{M}$ ) of sclareol. The extent of cell death was measured after a 48-h incubation period using an LDH release assay. Since the amount of LDH release from the dying cells into the culture medium is proportional to the amount of cell death, this assay provides an acceptable estimation of the cell death induced by sclareol. Fig. 2 shows the significant increase in the sclareol-induced LDH release in a dose-dependent manner compared with that of the control $(\mathrm{P}<0.05)$.

Sclareol induces apoptosis in osteosarcoma cells. The apoptotic effects of sclareol were evaluated in MG63 osteosarcoma cells exposed to different concentrations $(30,50,70$ and $100 \mu \mathrm{M})$ of sclareol for $48 \mathrm{~h}$. The osteosarcoma cells were stained and evaluated for nuclear morphological changes using an inverted fluorescence microscope. The untreated cells showed normal, evenly dispersed blue fluorescence within their nuclei, whereas sclareol-treated cells displayed chromatin condensation or dense staining fragmentation known as 'apoptotic bodies', which correspond to an early apoptotic event (Fig. 3) (9). Notably, at higher concentrations of sclareol, a more significant reduction in the total number of cancer cells was observed compared with that in the control cells, indicating that sclareol exerts potent apoptotic cell death effects at higher doses.

Sclareol induces $G_{1}$-phase arrest in osteosarcoma cells. Apoptosis and cell cycle deregulation are closely related biochemical events, and any disruption in cell cycle progression may lead to apoptotic cell death. In order to have a mechanistic overview of the growth inhibitory effect exerted by sclareol in osteosarcoma cancer cells, flow cytometric analysis was performed to detect whether sclareol induces cell cycle arrest in the MG63 cell line. The results indicated that treatment with varying concentrations of sclareol for $48 \mathrm{~h}$ induced $\mathrm{G}_{1}$-phase growth arrest in osteosarcoma cells (Fig. 4). Following a 48 -h treatment with 50,70 or $100 \mu \mathrm{M}$ sclareol, the $\mathrm{G}_{1}$-phase cell population was significantly increased from $56.02 \%$ in the DMSO control cells to $74.54,79.12$ and $88.21 \%$ in the 50,70 and $100 \mu \mathrm{M}$ sclareol-treated cells, respectively. This increase in the $\mathrm{G}_{1}$-phase cell population was accompanied by corresponding decreases in the $S$ and $G_{2}$ phases of the cell populations. In summary, the cancer growth inhibitory effects of sclareol can be explained on the basis that it induces strong $\mathrm{G}_{1}$-phase arrest in osteosarcoma cells.

Sclareol induces significant $1 \Psi$ m loss in MG63 osteosarcoma cancer cells. One important and indicative stage in the intrinsic apoptosis pathway is the depolarization of the mitochondrial membrane and the subsequent leakage of the outer membrane through pore formation. This is accompanied by the release of pro-apoptotic molecules and cytochrome $c$. The fluorescent dye $\mathrm{Rh}-123$ is a specific probe for the detection of alterations in the $\Lambda \Psi \mathrm{m}$ in living cells (10). The results of the current study revealed that sclareol induced a progressive reduction in the number of cells with intact $\Lambda \Psi \mathrm{m}$ and increased the number of cells with low $\Lambda \Psi \mathrm{m}$ after $48 \mathrm{~h}$ incubation. The loss of $\Lambda \Psi \mathrm{m}$ in osteosarcoma cells increased in a dose-dependent manner

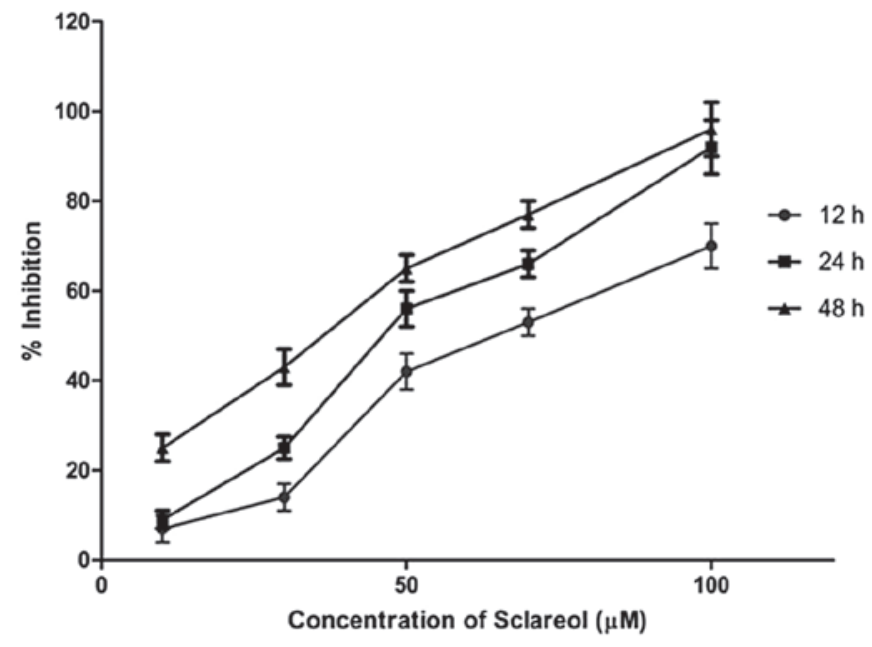

Figure 1. Time and concentration-dependent growth inhibition of osteosarcoma cancer cells induced by sclareol.

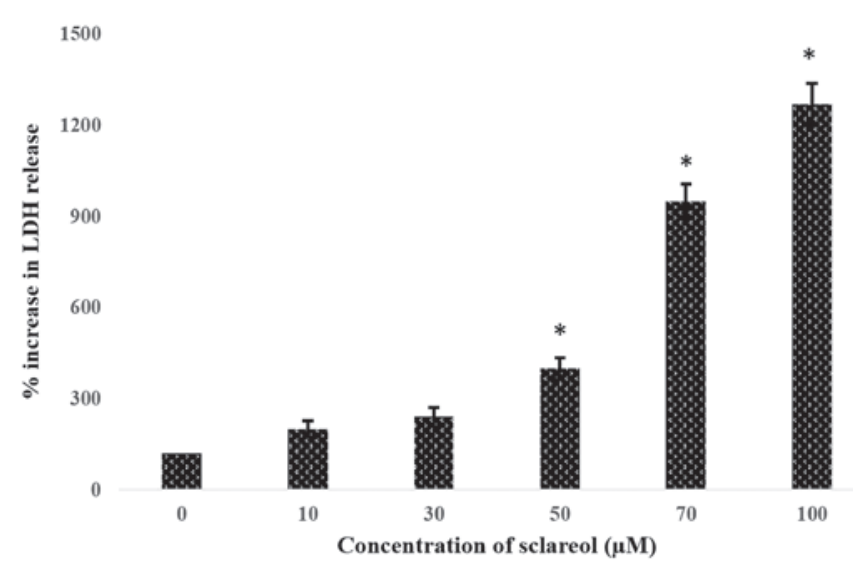

Figure 2. Concentration-dependent lactate dehydrogenase (LDH) release from MG63 osteosarcoma cells induced by 48-h sclareol treatment. ${ }^{*} \mathrm{P}<0.05$ vs. $0 \mu \mathrm{M}$

following treatment with 50,70 and $100 \mu \mathrm{M}$ of sclareol for $48 \mathrm{~h}$ (Fig. 5). The percentage of cells with a reduced $\Lambda \Psi \mathrm{m}$ was $15.0 \%$ in the solvent-negative control and 23.9, 22.2 and $74.0 \%$ at 50, 70 and $100 \mu \mathrm{M}$ sclareol, respectively. Thus, this experiment confirms that treatment of osteosarcoma cancer cells with sclareol induces a loss in $\Lambda \Psi \mathrm{m}$ significantly.

\section{Discussion}

Sclareol is a fragrant chemical compound found in Salvia sclarea from which it derives its name. It is a bicyclic diterpene alcohol with a sweet, balsamic scent. It is used as a fragrance in cosmetics and perfumes and as flavoring in food. From a pharmaceutical point of view, sclareol has been reported to kill human leukemic and colon cancer cells by inducing apoptosis. The addition of sclareol to cultures of HCT-116 human colon cancer cells resulted in the inhibition of DNA synthesis, the arrest of cells at the $G_{1}$-phase of the cell cycle, activation of caspases-8 and -9 , PARP degradation and DNA fragmentation $(11,12)$. The anticancer activity of sclareol in vivo has been assessed using human colon cancer xenograft/mouse models. It was observed that sclareol 


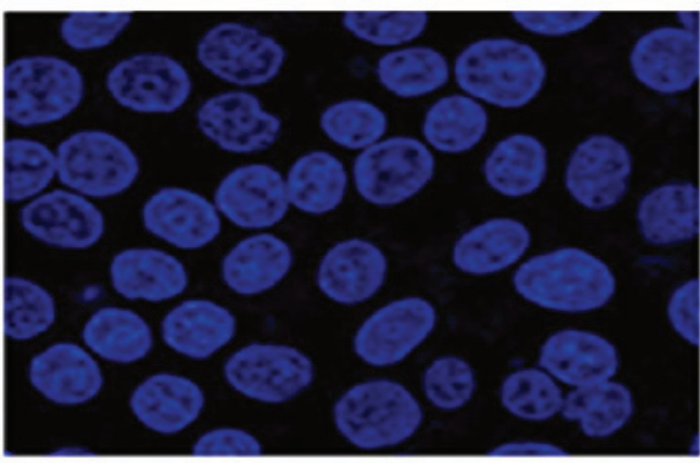

Control

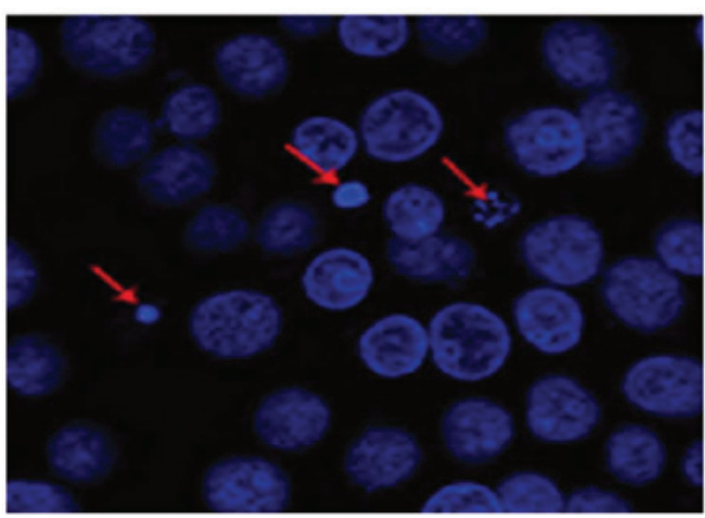

$50 \mu \mathrm{M}$

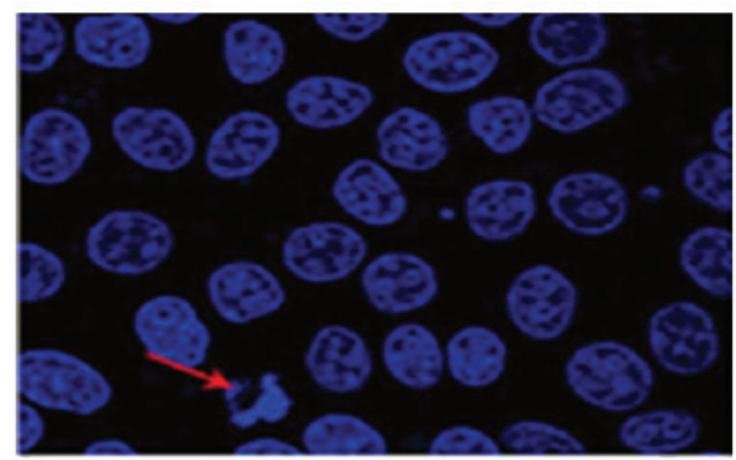

$30 \mu \mathrm{M}$

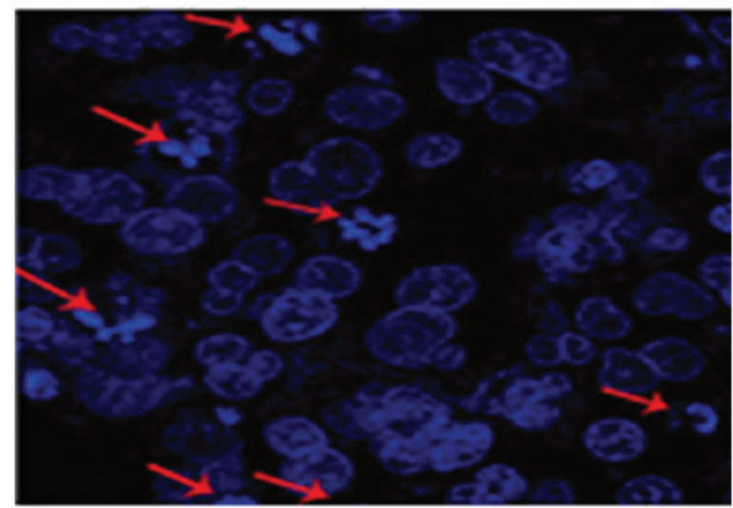

$70 \mu \mathrm{M}$

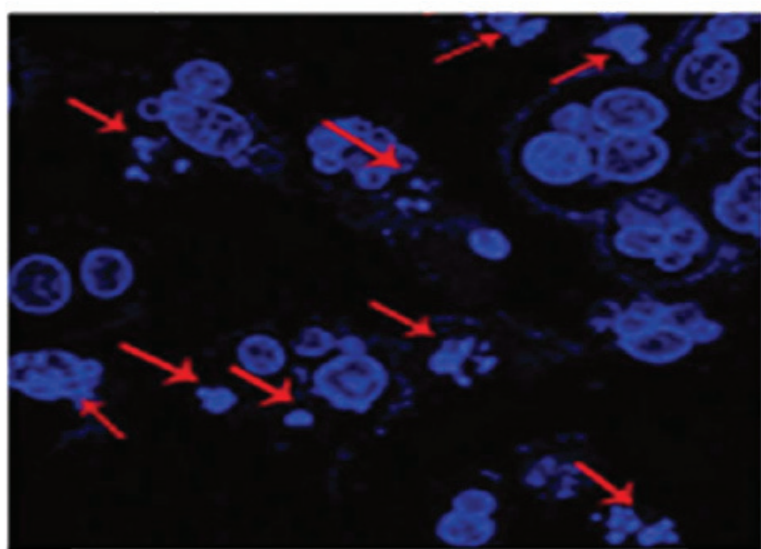

$100 \mu \mathrm{M}$

Figure 3. Assessment of apoptosis in osteosarcoma cancer cells using fluorescence microscopy following treatment with different concentrations of sclareol. Nucleolus morphological changes (apoptotic bodies) can be clearly observed at higher concentrations (magnification, x400; arrows indicate apoptotic body formation).

arrested the growth of p53-deficient human colon cancer cells and subsequently induced apoptosis through the activation of caspases- 8 and -9 in vivo (13). In another study, sclareol was reported to exhibit an anticancer effect against MN1 and MDD2 human breast cancer cell lines derived from the MCF-7 parental cell line. The study used flow cytometry to demonstrate that sclareol was able to inhibit DNA synthesis, induce cell cycle arrest at the $\mathrm{G}_{0} / \mathrm{G}_{1}$ phase and induce apoptosis independent of p53 status (14). An additional study reported that liposome-incorporated sclareol shows cytotoxic and antitumor activity against human colon cancer xenografts. The liposomal and free sclareol were initially tested in vitro for their activity against human cancer cells using the sulphorhodamine B assay. Liposomal-incorporated sclareol showed a reduction in the growth rate of human colon cancer cells in SCID mice, with no significant side-effects (15).

The present study investigated the anticancer activity of sclareol against MG63 osteosarcoma tumor cells, along with its effects on cell cycle progression and $\Lambda \Psi \mathrm{m}$, which is the first such study to be published to the best of our knowledge. The extent of cell death was measured with an LDH release assay, as the amount of LDH released from dying cells into the culture medium is proportional to the extent of cell death. Sclareol was shown to induce dose- and time-dependent cell death in MG63 
A

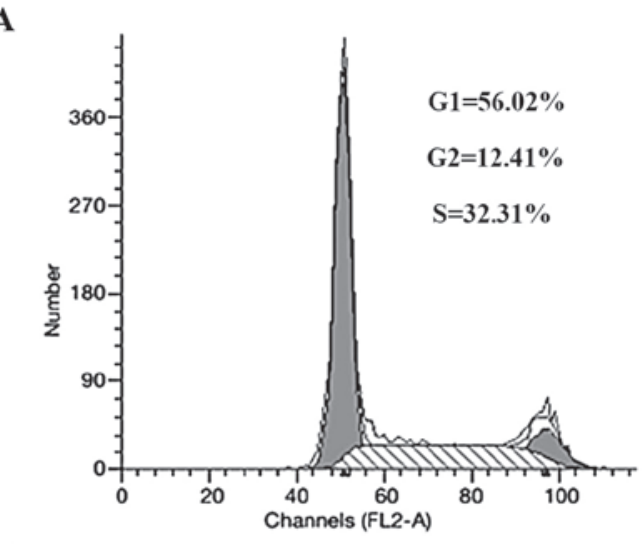

C

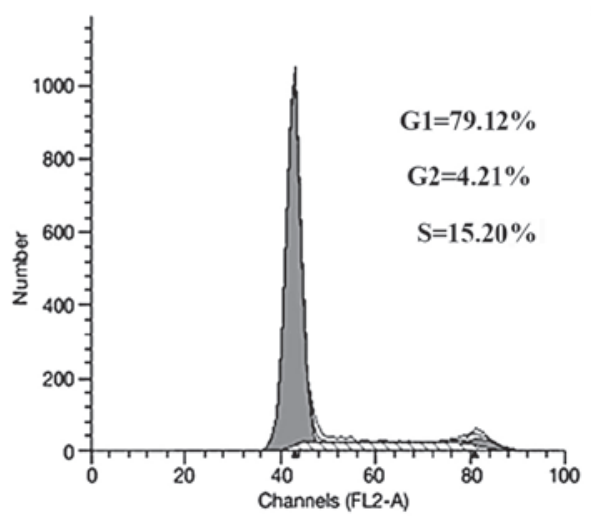

B

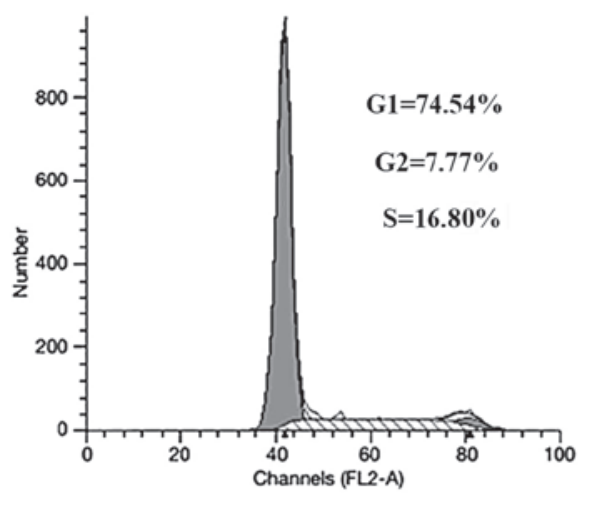

D

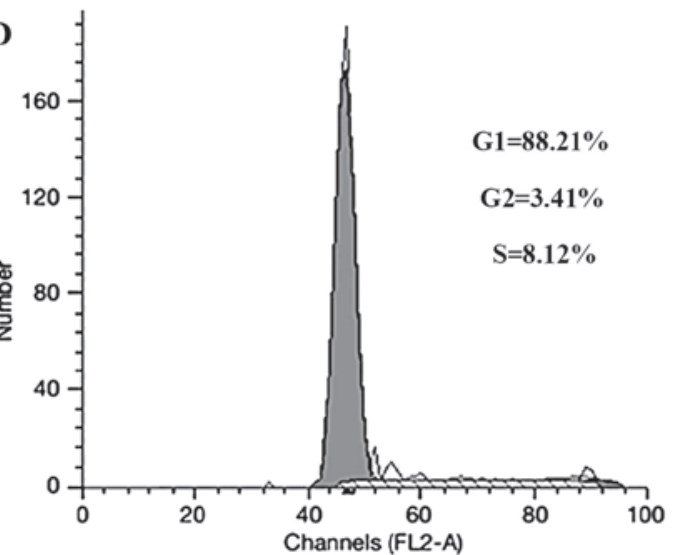

Figure 4. Effect of different concentrations of sclareol on the cell cycle phase distribution of osteosarcoma cancer cells. Cells were subjected to (A) 0, (B) 50, (C) 70 and (D) $100 \mu \mathrm{M}$ sclareol for $48 \mathrm{~h}$, and then stained with propidium iodide. Values are expressed as a percentage of the cell population in the $\mathrm{G}_{1}, \mathrm{~S}$ and $\mathrm{G}_{2}$ phases of the cell cycle.
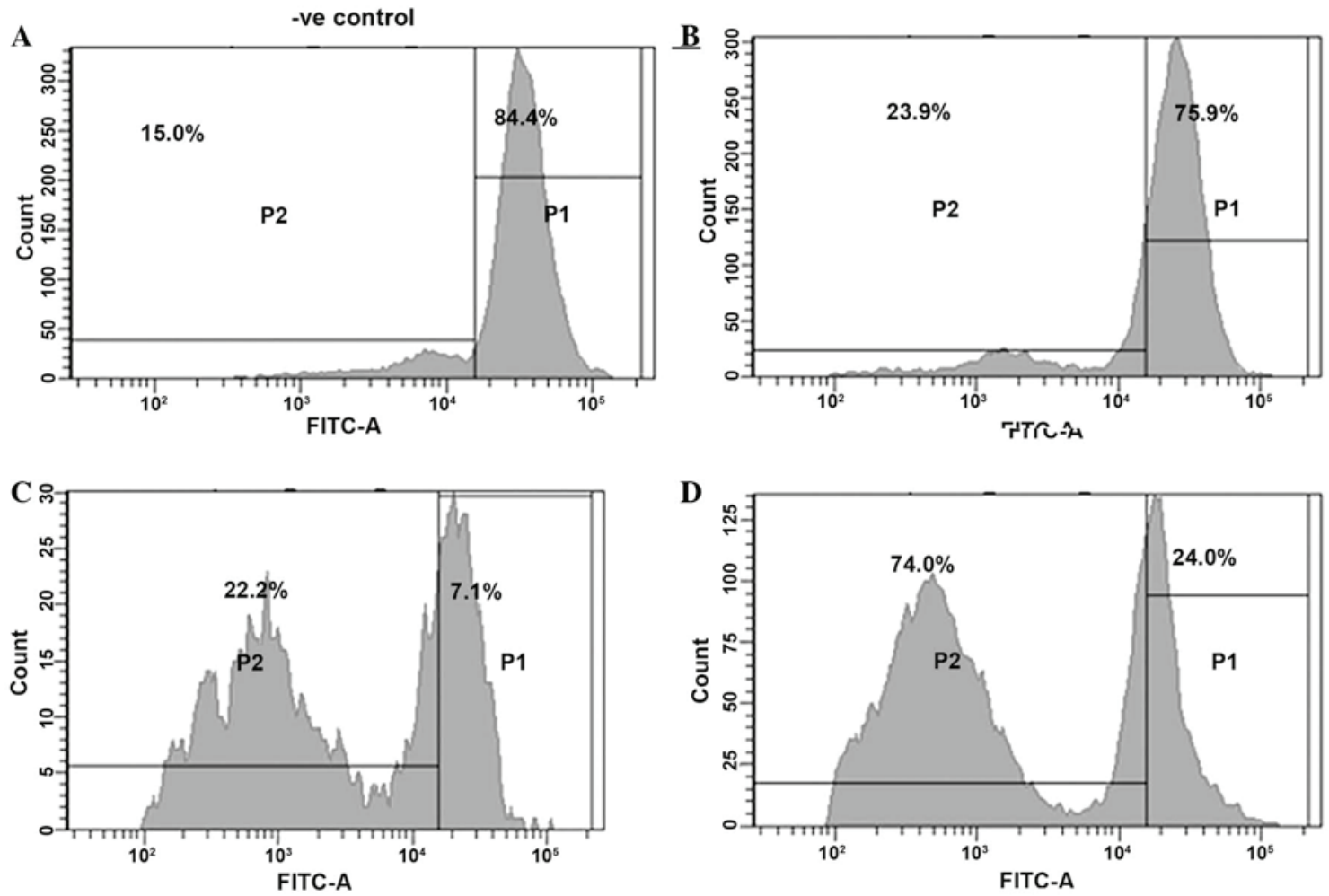

Figure 5. Flow cytometric analysis of the effect of sclareol on the loss of mitochondrial membrane potential in osteosarcoma cancer cells. (A) Negative control, (B) 50, (C) 70 and (D) $100 \mu \mathrm{M}$ sclareol. Representative results from three independent experiments are shown and each value represents the mean \pm standard deviation of three independent experiments. The percentages of cancer cells with reduced mitochondrial membrane potential were: (A) 15.0, (B) 23.9, (C) 22.2 and (D) $74.0 \%$. 
osteosarcoma tumor cells. Furthermore, following exposure to different doses of sclareol, morphological changes characteristic of apoptosis were detected in these cells using fluorescence microscopy. Flow cytometric analysis revealed that sclareol induces $\mathrm{G}_{1}$ cell cycle arrest in these cells. Following a 48-h treatment with 50,70 and $100 \mu \mathrm{M}$ doses of sclareol, the $\mathrm{G}_{1}$-phase cell population was significantly increased from $56.02 \%$ in the DMSO control cells to $74.54,79.12$ and $88.21 \%$, respectively. Using a Rh-123 fluorescent probe, it was revealed that sclareol caused a significant reduction in the $\Lambda \Psi \mathrm{m}$ in these tumor cells.

In conclusion, sclareol significantly inhibits the growth of osteosarcoma tumor cells by inducing apoptosis accompanied by $\mathrm{G}_{1}$ phase cell cycle growth arrest and a concomitant loss of $\Lambda \Psi \mathrm{m}$. Furthermore, fluorescence microscopy revealed that sclareol induces morphological changes characteristic of apoptosis in these cells. Taking all of the results into consideration, sclareol may be developed further as a possible anticancer agent for the treatment of osteosarcoma.

\section{References}

1. Wyllie AH: Apoptosis: an overview. Br Med Bull 53: 451-465, 1997.

2. Hengartner MO: The biochemistry of apoptosis. Nature 407 770-776, 2000

3. Enneking WF and Springfield DS: Osteosarcoma. Orthop Clin North Am 8: 785-803, 1977.

4. Ottaviani G and Jaffe N: The epidemiology of osteosarcoma. Cancer Treat Res 152: 3-13, 2009.
5. Ferguson WS and Goorin AM: Current treatment of osteosarcoma. Cancer Invest 19: 292-315, 2001.

6. Bacci G and Lari S: Adjuvant and neoadjuvant chemotherapy in osteosarcoma. Chir Organi Mov 86: 253-268, 2001.

7. Biermann JS and Baker LH: The future of sarcoma treatment. Semin Oncol 24: 592-597, 1997.

8. La Quaglia MP: Osteosarcoma. Specific tumor management and results. Chest Surg Clin N Am 8: 77-95, 1998.

9. Yang Y, Yang L, You QD, Nie FF, et al: Differential apoptotic induction of gambogic acid, a novel anticancer natural product, on hepatoma cells and normal hepatocytes. Cancer Lett 256: 259-266, 2007.

10. Johnson LV, Walsh ML and Chen LB: Localization of mitochondria in living cells with rhodamine 123. Proc Natl Acad Sci USA 77: 990-994, 1980.

11. Dimas K, Kokkinopoulos D, Demetzos C, Vaos B, et al: The effect of sclareol on growth and cell cycle progression of human leukemic cell lines. Leuk Res 23: 217-234, 1999.

12. Dimas K, Hatziantoniou S, Tseleni S, Khan H, et al: Sclareol induces apoptosis in human HCT116 colon cancer cells in vitro and suppression of HCT116 tumor growth in immunodeficient mice. Apoptosis 12: 685-694, 2007.

13. Mahaira LG,Tsimplouli C, Sakellaridis N, Alevizopoulos K, et al: The labdane diterpene sclareol (labd-14-ene-8, 13-diol) induces apoptosis in human tumor cell lines and suppression of tumor grow th in vivo via a p53-independent mechanism of action. Eur J Pharmacol 666: 173-182, 2011.

14. Dimas K, Papadaki M, Tsimplouli C, Hatziantoniou S, et al: Labd-14-ene-8,13-diol (sclareol) induces cell cycle arrest and apoptosis in human breast cancer cells and enhances the activity of anticancer drugs. Biomed Pharmacother 60: 127-133, 2006.

15. Hatziantoniou S, Dimas K, Georgopoulos A, Sotiriadou N and Demetzos C: Cytotoxic and antitumor activity of liposome-incorporated sclareol against cancer cell lines and human colon cancer xenografts. Pharmacol Res 53: 80-87, 2006. 